\title{
Mega-dose methylprednisolone (MDMP) for chronic idiopathic myelofibrosis
}

\author{
Kronik idiopatik miyelofibrosis için yüksek doz metilprednizolon (YDMP)
}

\author{
Şinasi Özsoylu
}

\section{To the E ditor,}

I would like to make few comments on Balcı and her colleagues' paper entitled "Complex cytogenetic findings in the bone marrow of a chronic idiopathic myelofibrosis patient" which was published in the recent issue of the Journal. [1].

Although the authors' cytogenetic findings looks original, it should be considered that chronic idiopathic myelofibrosis (CIF) is a colonal disorder like chronic myeloid leukemia (CML), polycythemia vera, etc.

Among them only Philadelphia chromosome (Ph1) is specific for CML, but mutations are present in all of these clonal disorders. I believe since the cytogenetic changes are not pathognomic or specific, these kind of studies should be carried only on research basis. In addition to radiation as mentioned by the authors makes the interpretation of their findings more questionable.

On this occasion, I would specifically like to emphasize the MDMP treatment for these patients which seems to be the only approach in the treatment of this disorder. In addition to some stem cell transplantation reports, MDMP is cheap, safe and easily applicable in all conditions.

Although we first reported patient with CIF in 1957 from this country [2], we treated almost a dozen of CIF cases without major complications in children and adults since 1983 [3-13]. MDMP treatment was mentioned in several occasions in this journal, we sorry that despite of its international consideration, except ITP treatment,my colleagues did not take it seriously [14].

\section{R eferences}

1. Balcı TB, Yüksel MK, Yılmaz Z, Şahin FI. Complex cytogenetic findings in the bone marrow of a chronic idiopathic myelofibrosis patient. Turk J Hematol. 2010;27:113-6.

2. Erman M, Özsoylu S. Sur un cas d'anemie splenique erythromyeloide de l'adulte. Presse Med 1957;65: 1309-11.

3. Özsoylu Ş, Ruacan Ş. High dose bolus methylprednisolone treatment for primary myelofibrosis. Eur J Pediatr 1983;140:810.

4. Özsoylu Ş, Ruacan Ş. High-dose intravenous corticosteroid treatment in childhood idiopathic myelofibrosis. Acta Haematol 1986;75:49-51.

5. Özsoylu Ş. Myelofibrosis with myeloid metaplasia. Blood 1986;67:253.

6 Özsoylu Ş. High-dose intravenous methylprednisolone for idiopathic myelofibrosis. Lancet 1988;1:766.

7. Özsoylu Ş. High-dose intravenous methylprednisolone for idiopathic myelofibrosis. Brit J Haematol 1988;70:388-9.

8. Özsoylu Ş. Mega dose methylprednisolone (MDMP) treatment. Turk J Pediat 2004;46:292.

9. Özsoylu S. Treatment of primary myelofibrosis. Turk J Hematol 2009;26:211-2.

10. Özsoylu Ş. High dose intravenous methylprednisolone (HIVMP) in hematologic disorders. Hematology Reviews 1990;4:197-207. 
11. Özsoylu Ş. Myelofibrosis in children. Pediatr Hematol Oncol 1994;11:337-40.

12. Özsoylu Ş. Myelofibrosis. Acta Hematol 1995;94:218.

13. Megadose metilprednizolon; resyonal kortikosteroid kullanımı (Eds.Y Karaaslan, A Kadayıfçı) 2004;70:70-4.

14. Bernini JC, Carrillo JM, Buchanon GR. High-dose intravenous methylprednisolone therapy for patient with Diamond-Blackfan anemia refractory to conventional doses of prednisone. J Pediat 1995;127:654-9.

\section{Reply}

\section{Dear Editor,}

We read the comments of Dr. Özsoylu about our recently published case report titled "Complex cytogenetic findings in the bone marrow of a chronic idiopathic myelofibrosis patient". We would like to thank Dr. Özsoylu very much for reminding us the importance of especially megadose methyl prednisolon for the treatment of different hematologic diseases.

Idiopathic myelofibrosis that is seen in adults is an incurable disease without allogeneic stem cell transplantation [1,2]. Many kinds of therapies such as chemotherapeutics [3,4] including busulfan, hydroxyurea, chlorambucil, 2-chlorodeoksiadenosamine; biologic response modifier regimens [5]; corticosteroids, anabolic steroids [5,6]; thalidomide $[7,8]$, lenalidomide [9] have been used but none of them has changed the biology of the disease and survival rates of patients [10]. Since there is no optimal therapy, the choice of the drug depends on the patient's characteristics and the physician's experience. Hydroxyurea was the drug of choice by the doctor who first saw him. When we met the patient, he was refractory to that therapy and had a very painful large spleen. Because of his comorbid conditions, splenic irradiation had been used to palliate his symptoms. The response was transient, as expected, and after a short period of time he died due to progressive disease.

As we have mentioned in the case report, most patients with primary myelofibrosis have karyotypic abnormalities at diagnosis and some of them have been associated with an adverse prognosis. A correlation between the presence of multiple chromosomal deletions and poor survival has been reported [10]. The reason for the development of new chromosomal abnormalities in this patient is a difficult question to answer. As you have mentioned it may be the radiation he received or the immunologic stimuli or the chemical agents and/or industrial solvents he had been exposed [10]. Whatever the reason, we have shown the abnormality and wanted to share this new knowledge with our colleagues studying in the same area.

\section{References}

1. Deeg HJ, Gooley TA, Flowers ME, Sale GE, Slattery JT, Anasetti C, Chauncey TR, Doney K, Georges GE, Kiem HP, Martin PJ, Petersdorf EW, Radich J, Sanders JE, Sandmaier BM, Warren EH, Witherspoon RP, Storb R, Appelbaum FR. Allogeneic hematopoietic stem cell transplantation for myelofibrosis. Blood. 2003;102:3912-8.

2. Rondelli D, Barosi G, Bacigalupo A, Prchal JT, Popat U, Alessandrino EP, Spivak JL, Smith BD, Klingemann HG, Fruchtman S, Hoffman R; Myeloproliferative DiseasesResearch Consortium. Blood.2005;105:4115-9.

3. Lofvenberg E, Wahlin A,Roos G, Ost A.Reversal of myelofibrosis by hydroxyurea. Eur JA Haematol.1990;44:33-8.

4. Faoro LN, Tefferi A, Mesa RA. Long term analysis of the palliative benefit of 2-chlorodeoxyadenosine for myelofibrosis with myeloid metaplasia. Eur J Haematol. 2005;74:117-20.

5. Barosi G, Hoffman R. Idiopathic myelofibrosis. Semin Hematol.2003; 42:248-58.

6. Cervantes f, Hernadez- Boluda JC, Alvarez A, Nadal E, Montserrat E. Danazol treatment of idiopathic myelofibrosis with severe anemia. Haematologica.2000;85-59 5-599.

7. Mesa RA, Steensma DP, Pardanani A, Li CY, Elliott M, Kaufmann SH, Wiseman G, Gray LA, Schroeder G, Reeder T, Zeldis JB, Tefferi A. A phase 2 trial of combination low dose thalidomide and prednisone for the treatment of myelofibrosis with myeloid metaplasia. Blood 2003; 101:2534-41.

8. Barosi G, Grossi A, Comotti B, Musto P, Gamba G, Marchetti M. Safety and efficacy of thalidomide in patients with myelofibrosis with myeloid mataplasia. $\mathrm{Br}$ J Haematol.2001; 114:78-83.

9. Tefferi A, Cortes J, Verstovsek S, Mesa RA, Thomas D, Lasho TL, Hogan WJ, Litzow MR, Allred JB, Jones D, Byrne C, Zeldis JB, Ketterling RP, McClure RF, Giles F, Kantarjian HM. Lenalidomide therapy in myelofibrosis with myeloid metaplasia. Blood 2006; 108: 1158-64.

10. Hoffman R,Ravandi-Kashandi F. İdiopathic myelofibrozis. In: Hoffman R, Benz EJ Jr, Shattil SJ, et al eds. Hematology: Basic Principles and Practices. 4th edition. Philedelphia, PA: Elsevier Scientific; 2005:1255-1257.

\section{Corresponding author:}

M.D. Feride Iffet Sahin,

Department of Medical Genetics, Baskent University Faculty of Medicine, Kubilay Sokak No:36 06570, Maltepe Ankara, Turkey

Tel: +90 3122324400 - 302

Fax: +903122319134 